\title{
Mode of Production In Fishermen Community: Case Study of Relationship Between the Ship Owner and Labour of Fishermen in Pulau Baai Area, Bengkulu City
}

\author{
Elia Damayanti1), Septri Widiono1)*, Satria Putra Utama1) \\ 1) Socio Economic of Agriculture Department, Faculty of Agriculture, University of Bengkulu \\ *Corespondence author email: septriwidiono@unib.ac.id
}

\begin{abstract}
Modernization in catch fisheries sector by mean machinary application for fishing could be devided into some phases. Every phases showed some production relation between the ship owners and their labours. In the Marxist tradition of thought, the study about these relationship could be gained by elaborate the mode of production. For more specific, this study were elaboratethe mode of production in every phases of modernization. Mode of production consisted force of production and relation of production. In this context, force of production was mean of production like ships, net and seine. While relation of production wasthe organization of fishermen, power and control by the owners to their labours. The study was conducted by using qualitative method so depth interviewed of some key informants had been main method in collecting datas. The results of the study indicated that fisheries modernization in research area held into four phases. We called them as period oflancang, trawl, bagan, and purseseine. Further more, the mode of production in every phases as follow namely, lancang was subsistence production, trawl was commercialist production, and bagan was commercialist production. While purseseine had has two mode of production, namely commercialist production for Bengkulu's owner and capitalist production for Chinese's owner.
\end{abstract}

Keywords : mode of production, Pulau Baai, Lancang, Trawl, Bagan, and Purse Seine.

Citation to this paper should be made as follows :

E. Damayanti, S. Widiono, S. P. Utama. 2018. Mode of Production In Fishermen Community: Case Study of Relationship Between the Ship Owner and Labour of Fishermen in Pulau Baai Area, Bengkulu City. Agritropica: Journal of Agricultural Science. 1 (2): 100 - 112.DOI: https://doi.org/10.31186/I.Agritropica.1.2.100$\underline{112}$

\section{INTRODUCTION}

Based on position, the fishermen were divided into two classes. First one was fishermen who have production equipment to catch fish such as boats and other capital, which are usually referred to as juragan (bosses). The second, nelayan buruh, fishermen who only have skill especially hard working skill. They work as laborer.

The concept mode of production was the old concept in Marxist school of though. Mode of production was formed from force of production and relation of production (Taylor 1979). Force of production consist of some means of production which using in any activity to produce any product. Means of production under control by upper class. In the contex of catch fisheries sector, means of production were ships and catch equipment (Satria 2001). Further more, where modernization in catch fisheries sector held by applying machinary boat, we would consider that social relation be more rational. The relation between juragan and nelayan buruh taken place in more calculative consideration.

Modernization cannot be discharged from capitalism symptom. Capitalism was 
economic system that enabling some individuals to control vital resources which they used to maximize the advantages (Satria 2001, Sztompka 2004). Acording to Sanderson (2000), in modern capitalism, forces of production principly owned by a few people, and this small capitalist group instructed the entire economic production processed. This social structure called social formation of capitalist. While social formation here defined as Taylor noted, " $a$ social formation which is dominated by an articulation of (at least) two mode of production - a capitalist and a non-capitalist mode- in which the former is, or is becoming, increasingly dominant over the other." (Taylor 1979).

One of the important aspect in modernization was division of labor system appearance and also profit sharing in fisherman community. For fishermen which do not have enough capital, hence will be employed by the juragan. The fishermen worked according to their ability or skill and contracted that the fees will be given after the marine products were sold. In this new social formation refered at appearance of capitalist mode of production which depict that juragan giving fee (money) to its worker according to the contract. But, in fisherman with profit sharing system, the capitalist mode of production did not fully conceived because of their social consideration in their relation.

Wijayanti (2008) found that the work relationship in Pati fishermen places more emphasis on fulfilling the rights and obligations of juragan and their workers. The role of the juragan was to invest the capital in the form of ships and equipment for the full arrest. Whereas workers were operating the fishing gear. This working relationship begans with the period of recruitment of workers, where workers came alone to establish working relationships with juragan according to the agreed convention. In general, this agreement was carried out verbally, not formally (unwritten). The profit sharing system was agreed upon when the employment relationship was formed, net income after deducting retribution fees for juragan and bakul fishermen, provisions and operationals, then divided fifty-fifty between the juragan and the laborers.

Other research showed any spesific characteristic inhered within the relationship. Sukmawati (2008) who conducted research in the fisherman community located in Pantai Utara Jawa (Pantura), found some evidence. First, an overview of the social structure of fisherman communities in Pantura from several juragan that exist were divided into several groups of juragan, namely juragan entrepreneurs, juragan coolie, juragan captain, and side-juragan. Second, the symbiosis that occurs was mutualism, namely the symbiosis of mutual need between the juragan and the laborer and vice versa. However, given the large number of labor fishermen with high levels of dependence on employers, so the position of labor fishermen were still not fully benefited.

From here, we can draw a conclusion that the modernization in the catch fisheries sector has changed relationship between juragan and nelayan buruh. Technology was a prime mover in alterating the mode of production from one type to the other. So we can call it that mode of production changed in every 
phase of modernization in the fisheries sector. In fact, the potential of fisheries resources, especially in Bengkulu Province, which is on the west coast of Indonesia, causes a lot of activities or businesses in the fisheries. Fish Landing Port or Pelabuhan Pendaratan Ikan (PPI) Pulau Baai was the largest port in Bengkulu Province, where the majority of the population were fishermen. Acording to BPS (2015), there were about 12.806 persons who dependending their livelihood on this sector. This was designate that catch fishery sector has important role in order to realize prosperity. Therefore, this paper will explorate the characteristic of mode of production in each phase of modernization in Pulau Baai area, Bengkulu City.

\section{RESEACRH METHODS}

This is a qualitative research using case study strategy (Bungin 2007). The case selected was the relation between juragan and their laborer. The location of the study was determined purposively in Pulau Baai Area because Pulau Baai was the largest production of fisheries in Bengkulu Province. The data were collected start from February to March 2016. Unit of analysis in this research was ship organization. The organization of the ship consists of juragan (bosses) and the crews consist of captain, crew member or ABK (Anak Buah Kapal), and chef. The data were collected using indepth interview of some informants, i.e. juragan (3 men), laborer/Anak Buah Kapal=ABK (3 men), PPI staff of Pulau Baai (1 man), community leaders or senior fishermen (1 man), and local government (1 man).
Beside conducting interview, data were collected using observation. The location of observation were PPI Pulau Baai. We observed activities of fishermen who aucting their marine catches. Secondary data also collected in order to give supporting the primary data collected by in-depth interview and observation. We obtained the secondary data from government agencies, i.e PPI Pulau Baai and Kampung Melayu Subdistrict Office.

Data were analyse qualitatively. We choosed the typology of mode of production proposed by Kahn (1980) in explaining Minangkabau social formation. We adapted his theory -from peasant community to fisherman communityabout three kinds mode of production because of the emerging modernization in catch fisheries sector as capitalist penetration in the local community. The capitalist penetration generally would be understood as the domination one mode of production, and the other mode of production was subordination.

Briefly, the typology of mode of production adapted from Kahn (1980) summarized as follow. First, Subsistence Production, working system that not exploitated both the natural resources and labors (fishermen in small group). The methods of catching were still traditional with small-sized equipments and only to fulfill their own needs. Second, Commercialist Production or Petty Commodity Production, the characteristics of knowing production for sold with more modern equipment than subsistence production. The methods of arrest were modern but still use a family system both in recruiting ship crews and catching the catch. Third, Capitalist Production, refered 
Table 1 Hierarchical levels in relation of ownership

\begin{tabular}{|c|c|c|c|c|c|}
\hline \multirow[t]{2}{*}{$\overline{\text { No }}$} & \multirow[t]{2}{*}{$\begin{array}{l}\text { Level of } \\
\text { Control }\end{array}$} & \multirow[t]{2}{*}{$\begin{array}{l}\text { Economic relationship } \\
\text { (control of what is produced) }\end{array}$} & \multicolumn{2}{|c|}{$\begin{array}{l}\text { Domination relationship (control of } \\
\text { how are produced) }\end{array}$} & \multirow[t]{2}{*}{ Legal ownership } \\
\hline & & & $\begin{array}{l}\text { Control } \\
\text { production } \\
\text { equipment }\end{array}$ & Control of labor & \\
\hline 1. & $\begin{array}{l}\text { Full } \\
\text { control }\end{array}$ & $\begin{array}{l}\text { Control of entire investment } \\
\text { process and accumulation }\end{array}$ & $\begin{array}{l}\text { Control of all } \\
\text { production } \\
\text { equipment }\end{array}$ & $\begin{array}{l}\text { Control over the } \\
\text { entire hierarchy of } \\
\text { supervision }\end{array}$ & $\begin{array}{l}\text { Shares to } \\
\text { guarantee } \\
\text { investment and } \\
\text { accumulation }\end{array}$ \\
\hline 2. & $\begin{array}{l}\text { Partial } \\
\text { Control }\end{array}$ & $\begin{array}{l}\text { Roles in overall production } \\
\text { decisions or partial aspects } \\
\text { and the entire investment } \\
\text { process }\end{array}$ & $\begin{array}{l}\text { Control of one } \\
\text { part of the entire } \\
\text { production } \\
\text { process }\end{array}$ & $\begin{array}{l}\text { Control of one } \\
\text { part of the } \\
\text { supervision } \\
\text { hierarchy }\end{array}$ & $\begin{array}{l}\text { Shares to } \\
\text { guarantee profits } \\
\text { (shares an } \\
\text { important part of } \\
\text { income) }\end{array}$ \\
\hline 3. & $\begin{array}{l}\text { Minimu } \\
\text { m } \\
\text { Control }\end{array}$ & $\begin{array}{l}\text { Control of what is produced } \\
\text { in the direct production } \\
\text { process itself }\end{array}$ & $\begin{array}{l}\text { Control of how } \\
\text { the production is } \\
\text { done }\end{array}$ & $\begin{array}{l}\text { Control of directly } \\
\text { producers, and } \\
\text { labor but not part } \\
\text { of the actual } \\
\text { hierarchy }\end{array}$ & $\begin{array}{l}\text { Little share } \\
\text { ownership } \\
\text { (shares are not } \\
\text { part of income) }\end{array}$ \\
\hline 4. & $\begin{array}{l}\text { No } \\
\text { control } \\
\text { at all }\end{array}$ & $\begin{array}{l}\text { Full exclusion from } \\
\text { participation in decisions } \\
\text { about what is produced }\end{array}$ & $\begin{array}{l}\text { Meaningless } \\
\text { control over } \\
\text { aspects and means } \\
\text { of production }\end{array}$ & $\begin{array}{l}\text { There is no ability } \\
\text { to impose } \\
\text { sanctions on other } \\
\text { workers }\end{array}$ & $\begin{array}{l}\text { Don't have } \\
\text { shares at all }\end{array}$ \\
\hline
\end{tabular}

Source: Wright as quoted by Satria (2001)

to exploitation of natural resources (marine) for profit. The average worker was a large group of 16-20 people with a system of division of labor and wages. They used large and modern ships and fishing gear.

Further more, the relation between juragan and nelayan buruh would be analyzed using level of control as proposed by Wright (Table 1).

\section{RESULTS AND DISCUSSION}

Regional development and population of the Pulau Baai region are in line with the modernization of capture fisheries in this region. The entry of residents and technology from outside made changes to the fleet, fishing gear, and fishing systems aimed at increasing the quantity and quality of capture fisheries. The period of development of fisheries modernization in Pulau Baai is divided into 4 periods based on dominant fishing gear and fleet over time.

\section{Modernization Period 1960-1980: Period of Lancang}

In the early 1960's when many Bugisnese came to Pulau Baai area, they used lancang with outboard motors for transportation and fishing. Then followed by other people who mostly came from outside, namely Minang people. The use of outboard motors on lancang was increasingly popular when many Bengkulu native fishermen began to adopt it. The characteristics of modernization in phase of lancang can be seen in Table 2. 
Table 2 Modernization in Phase of Lancang 1960-1980

\begin{tabular}{|c|c|}
\hline Characteristics & Description \\
\hline a. Typologi Mode of Production & Subsistence Production \\
\hline \multicolumn{2}{|l|}{ b. Force of Production } \\
\hline - Ships & - Lancang, Cadik Boat/Jukung/Sampan with outboard engine \\
\hline - Catching equipment & - Fishing rod, fishnet, $b u b u$ \\
\hline - Mean of production & - Traditional \\
\hline - Labor & - Free labor \\
\hline \multicolumn{2}{|l|}{ c. Relation of production } \\
\hline - Size of production unit & - 3-5 men \\
\hline - Structure & - Egalitarian \\
\hline - Character & - Non-exploitative \\
\hline d. Marine product & $\begin{array}{l}\text { Squids, shrimps, snappers, groupers, beledang fisheris, } \\
\text { tunas, gaguk fisheris and ect }\end{array}$ \\
\hline \multicolumn{2}{|l|}{ e. Ship Owner's Control Level } \\
\hline $\begin{array}{l}\text { - Economic relations (control of } \\
\text { what is produced) }\end{array}$ & - Full control \\
\hline \multicolumn{2}{|l|}{ - Control Relation } \\
\hline 1. Control of production tools & - Full control \\
\hline 2. Control of labors & - Full control \\
\hline
\end{tabular}

Source: Primary data processed (2016)

Lancang period of modernization was included subsistence production due to the following:

1. The boat used a small capacity size of 3-4 GT with an outboard engine.

2. Still dependent on the seasons and weather conditions.

3. Relatively short operation of the ship, only overnight.

4. There was no division of labor.

5. The haul only to meet daily needs.

The division of labor structure in Lancang period could be seen in Figure 1 as follow.

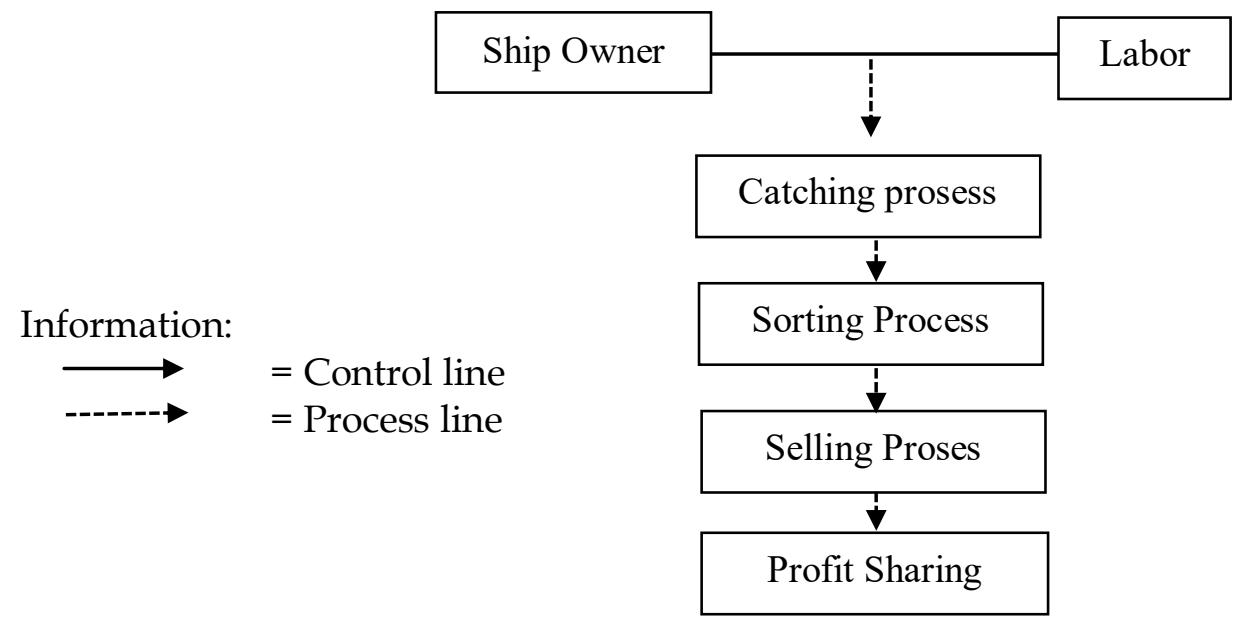

Figure 1 Organizational Structure in Lancang Period

Generally, lancang's owner fishing 2-3 man as a crew. The recruitment of crew with family, relatives or neighbors. members by ship owners cames from Recruitment was not disseminated by word family, relatives or neighbors. The of mouth because the owner only requires agreement was made only overnight then it 
will end when the results have been obtained after finishing the seaward.

The organization or division of labor was relatively equal between the owner of the ship and his crew because the operation was relatively short, just overnight was carried out, owner as a captain, he employing his family, friends or neighbours as crew members. Illustration of the results stated by the respondents as follows (interview to Mr. Zen on 1/3/2016).

Amount of catch: 500,000 minus 120,000 for fuel remain: 380,000 divided by 2 for owners $\approx 190,000$ rupiah.

\section{Modernization Period 1980-1990: Period of Trawl}

The juragan was introduced in the Trawl period with the arrival of bosses from the Sibolga area in the 1980s. Bataknese who came first was Jonggi Manurung with his friend an Acehnese called Candra, North Sumatra Province
(Arios \& Ajisman, 2003). Bataknese dominated the ownership and control of trawl. The characteristics of modernization in phase of trawl can be seen in Table 3 .

Mode of production in Trawl was included in commercial production because:

1. Juragan system was began.

2. Capacity of the ship was larger and fishing gear was bigger and more modern than before.

3. Operation of the ship was larger capacity and already handling hauls.

4. There was a division of labor in the crew.

5. The hauls was sold and profit sharing is carried out between juragan and crew

Recruitment of crews by juragan carried out with a tekong. Juragan only chooses tekong as "right-hand man". Trawl ship in the Pulau Baai area was relatively small, which had a crew about 5-6 man with an operating time of midnight.

Table 3 Modernization in Phase of Trawl 1980-1990

\begin{tabular}{|c|c|}
\hline Characteristics & Description \\
\hline a. Typologi Mode of Production & Commercialist Production \\
\hline \multicolumn{2}{|l|}{ b. Force of Production } \\
\hline - Ships & - $\quad$ Trawl, Fishing Ships \\
\hline - Fishing gear & - $\quad$ Trawl nets, fishing rods \\
\hline - Mean of production & - $\quad$ Modern \\
\hline - Labor & - Fisherman work as laborer \\
\hline \multicolumn{2}{|l|}{ c. Relation of production } \\
\hline - Size of production unit & - $\quad 3-5$ men \\
\hline - $\quad$ Structure & - Simple hierarchical \\
\hline - Character & - Non-exploitative \\
\hline d. Marine product & $\begin{array}{l}\text { Shrimps (shrimp trawl, double shrimp trawl rig) and } \\
\text { shell fishes, palak batu species, geleberan, bawal, } \\
\text { beledang, kembung, squids, crabs, cucut ect }\end{array}$ \\
\hline
\end{tabular}

e. Ship Owner's Control Level

- Economic relations (control of - Partial Control what is produced)

- Control Relation

1. Control of production tools - Partial Control

2. Control of labors - Partial Control

Source: Primary data precessed (2016) 
The structure of the division of labor in trawl can be seen in Figure 2.

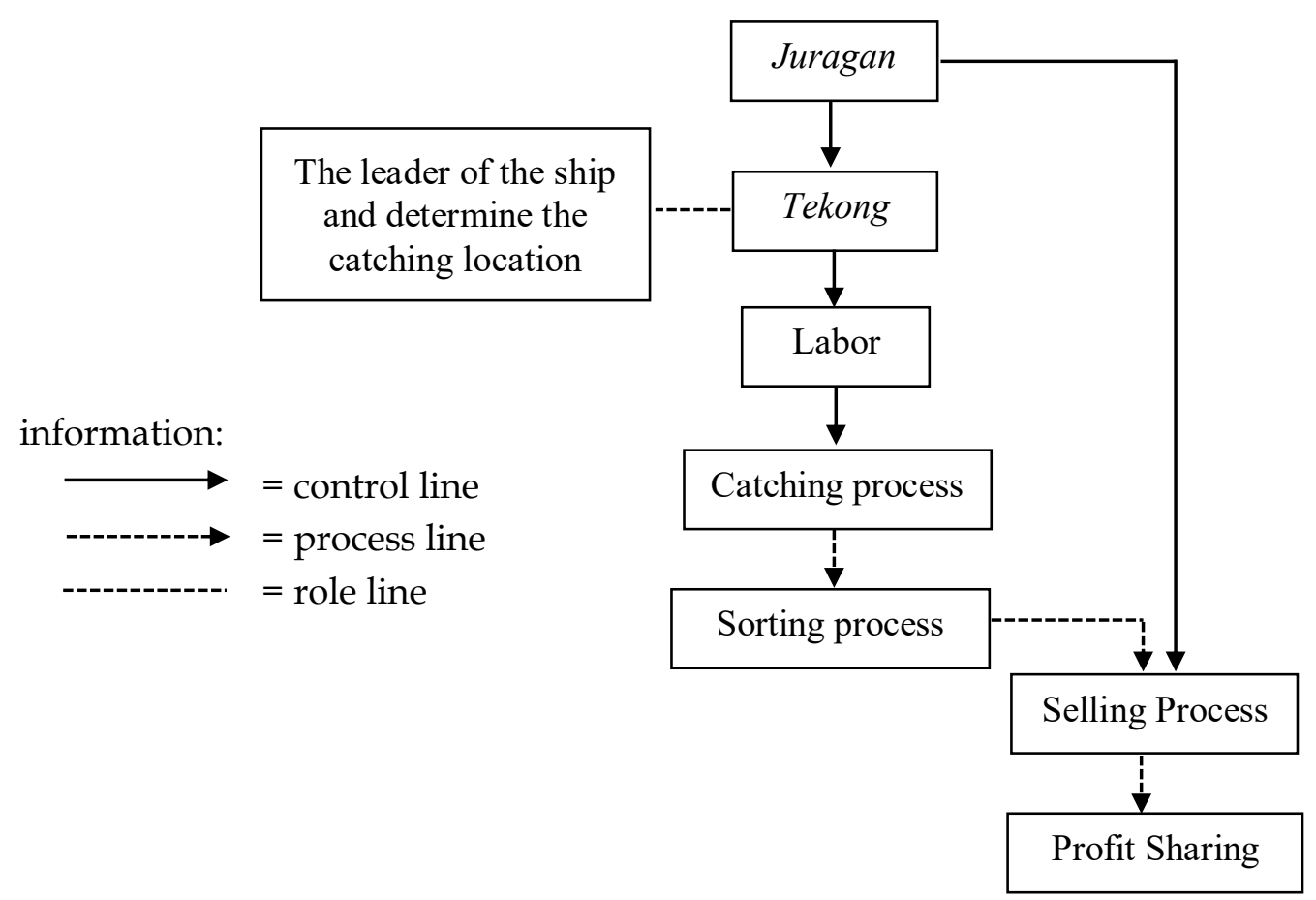

Figure 2. Organizational Structure in Trawl Period

With a relatively small crew, it was enough to be handled by the tekong if the crews turned over for any reason. The fishermen who were working on a trawl ship said that the results of trawling obtained were quite large and sufficient to meet the needs but sometimes many fishermen complained because of the difficulty in sorting the catch. Due to the size of the trawl net was so small, all types and sizes of fish will be caught in the net, even including coral dung if the net passes through the reef.

The illustration of the results presented by the respondents as follows (interview to Mr Riko on 16/3/2016).

Amount of catch: 15 million rupiahs (for once trip of shipping)

Food supplies: 4 million rupiahs

Remain: 11 million, $30 \%$ for ship maintenance costs $=7.7$ million
For juragan $=3.85$ million, remain 3.85 million $10 \%$ for tekong, remain 3.465 million So per ABK got 3.465 millon : $4=866,250$ rupiahs and tekong got $866,250+10 \%$ of 3.85 million $=1.251 .250$ rupiahs

\section{Modernization Period 1990-2000: Period of Bagan}

Ship namely Bagan came to Pulau Baai in 1980 and exist in 1990 used the modern technology such as radar and computers in 1997. Bagan was originally used by Bugis fishermen by buying from other regions, then followed by Minang fishermen with a catchment area of West Sumatra waters that only stopped to sell the catch in Pulau Baai.

The process of fishing on bagan was carried out at night with the help of spotlights as a fish catcher. The catching area of the bagan was predetermined area by first placing rumpon. Since 1997, fishing began using satellite systems and 
Table 4 Modernization in Phase of Bagan 1990-2000

\begin{tabular}{|c|c|}
\hline Characteristics & Description \\
\hline a. Typologi Mode of Production & Commercialist Production \\
\hline \multicolumn{2}{|l|}{ b. Force of Production } \\
\hline$\overline{- \text { Ships }}$ & - Bagan \\
\hline - Fishing gear & - $\quad$ Lift net \\
\hline - Mean of production & - $\quad$ Modern \\
\hline - $\quad$ Labor & - $\quad$ Fisherman as labor (Nelayan Buruh) \\
\hline \multicolumn{2}{|l|}{ c. Relation of production } \\
\hline - Size of production unit & - $\quad$ 15-20 men \\
\hline - Structure & - Simple hierarchical \\
\hline - Character & - Exploitative \\
\hline d. Marine product & Teri, cakalang, beledang, squids \\
\hline \multicolumn{2}{|l|}{ e. Ship Owner's Control Level } \\
\hline $\begin{array}{l}\text { - Economic relations (control of what is } \\
\text { produced) } \\
\text { - Control Relation }\end{array}$ & - Partial control \\
\hline 1. Control of production tools & - Partial control \\
\hline 2. Control of labors & - Partial control \\
\hline
\end{tabular}

Source: Primary data processed (2016)

computers on fishing boats to find out the existence of fish. The characteristics of modernization in phase of bagan can be seen in Table 4.

Mode of production in Bagan was commercialist, because of the following:

1. Bagan had more modern methods of catching up and not taking up a lot of time and energy.

2. Using modern technology.

3. Longer operation of ships for larger capacity and already handling hauls.

4. There was a division of labor for the crew.

5. The entire sold and profit sharing was carried out between skipper and ABK about 4 trips a month.

Just like trawl, juragan of bagan also choose tekong as right-hand man. Tekong led the ship as a captain who lead 15-20 man as a crew. They operate the bagan for fishing for 1 to 4 weeks. Juragan only chooses the tekong as captain then tekong should recruite some labor or $\mathrm{ABK}$.
Tekong was chosen by the juragan who experienced and expert in his field. Usually tekong of bagan were Bugisnese and Minangnese. After the tekong recruited $\mathrm{ABK}$, then tekong chooses a kuanca or ship mechanic and a chef who has responsible in cooking for the entire crew. The structure of the division of labor in bagan can be seen in Figure 3.

The relationship of production in bagan was a simple hierarchical. An organizational structure and position were exist within the ship. Though in trawl there was already the tekong as the leader of the ship, but there was no specialization. The tekong and his ABK did all of the activities during fishing together. While on the bagan there was a division of labor, although not specifically one person does one activity. When a kuanca or boat chef have complete their work, they will help again other crew members in catching the fish or sorting the catched.

There were quite a lot of boat crews (15-20 men), and the length of the fishing 


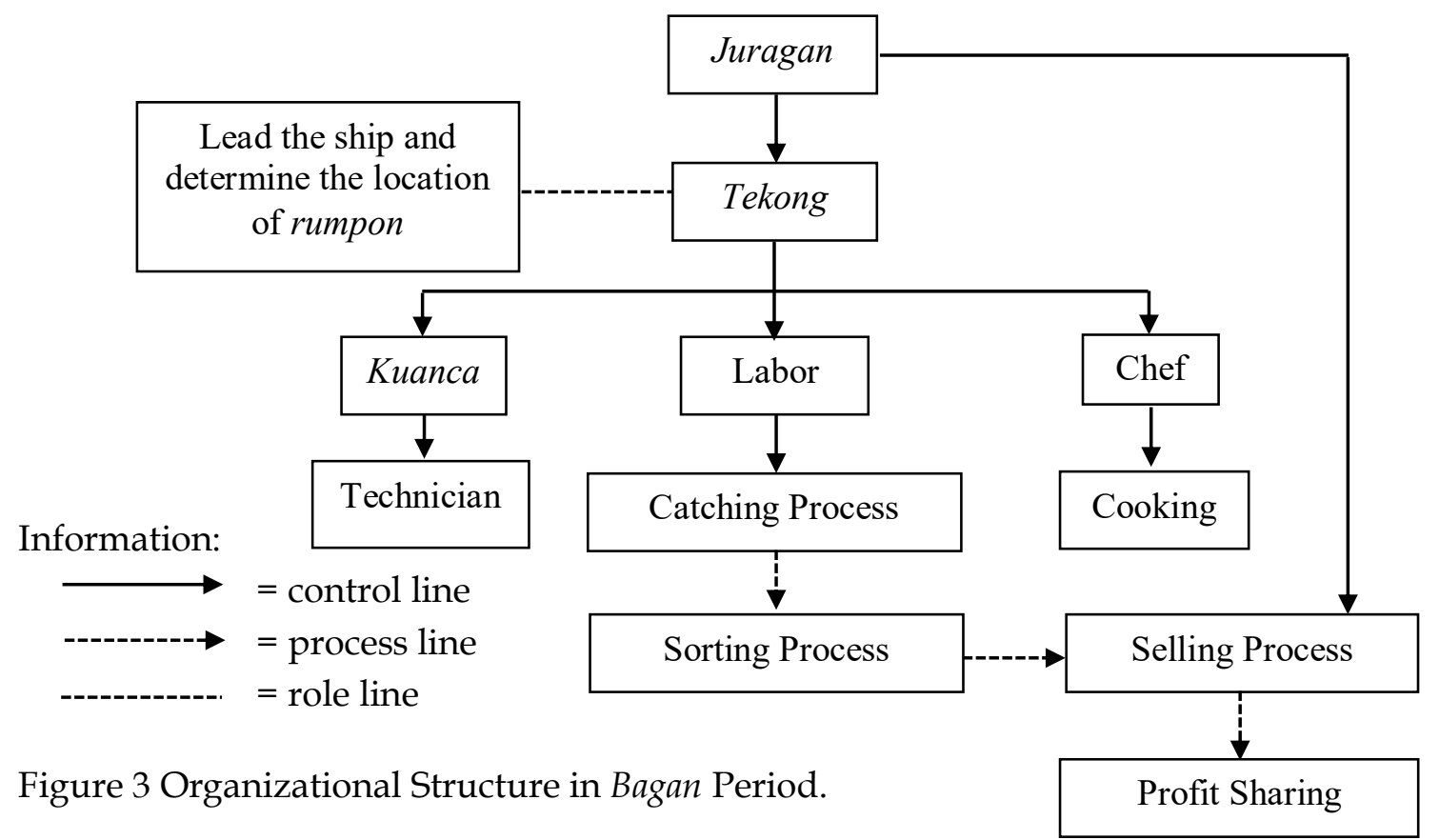

trip (1-4 week) have made the juragan have to provide facilities to avoid the saturation of the crew. ABK only have 1-2 days to rest on the mainland, after that they have to go to the sea again. Therefore, the juragan facilitates the ship with a number of equipment such as television, radio, and refrigerator like a home. In addition, the juragan also provides food supplies not only staples, but also food for snacks or food for takjil if going to the sea in Ramadan moon.

Although there were many supporting facilities provided by the juragan, but all costs incurred due to the equipment and food ingredients will be taken into account in the distribution of results. ABK receives profit sharing after deducting all the accommodation costs during fishing. The distribution of profit sharing was carried out after four trip. Lets see the illustration below (interview to Mr. Ben on March 18, 2016).

\section{$\underline{\text { Trip } 1}$}

Amount of catch: 50 million rupiahs Food supplies: 20 million
Remaining: 30 million;

Remaining: 30 million $10 \%$ for seller commission: 3 million

Remaining: 27 million

The remaining trip 1 was used as additional capital for trip 2 . Then, the last trips will be completed in a month divided by 2 for ship owners and all crew members. The ABK section will be divided into all of the crew coordinated by tekong.

Modernization Period 2000-now: Period of Purse Seine

Purse Seine was first owned by Chinese who bought directly from Java. In Java Purse Seine has been used by fishermen since the 1980s. At that time only a few Chinese people had Purse Seine and Acehnese juragan who occasionally came to Pulau Baai. Then in early 2000, Efendi, a juragan from Bengkulu began buying several Purse Seine ships.

Purse Seine was very rare because the price was very expensive. It takes about 5 billion rupiah to buy a ship body, 700 million for engines, and 2 billion for fishing gear. Until now, the Purse Seine, which was 
located in the PPI of Pulau Baai, has 12 ships, which were 8 ships owned by juragan Bengkulu and 4 ships belonging to juragan Chinese.

The Purse Seine ships have already used very sophisticated equipment with computers and device connected to the satellites. The purse seine catchment area was a catchment area that were still marked by rumpon and protected by laws such as land ownership rights so that they have to pay tax. Purse Seine operated to catch fish in midwater or mid-area such as Pelagis, Tuna, and Cobk whose lives were clustered. This kind of the ship has a very large capacity that capable to transportate the catches up to 10 tons.

We can summarize the characteristics of the production of purse seine as follows: (1) A boat owner was a person who has large capital who usually owns many ships and other businesses by employing many people including fishermen. (2) The catch was mostly handled by itself for export and marketing purposesfor outside region. (3) Well organized and planned.

The mode of production of Purse Seine tends to be capitalist even though there were juragan namely Bengkulu juragan who still used profit sharing system in their shiping.

There were five people who play a very important role in the ship. These people were tekong or captain of the ship, who was in charge of leading the ship; Apit or can be called a vice-captain, tasked with selecting and being responsible for ABK by seeing whether their physically were fit or not and ready to depart or not; then kuanca or mechanician who responsible for machinery such as oil changes, oil and for damage and maintenance of machinery; the kepala palung who in charge of preparing bait when fishing, and the chef who in charge of food preparating for the entire crew of the ship. The juragan only chooses Tekong and Apit, while the other crew members were chosen by Apit. They must work together under the leadership of Tekong for the success and safety of the entire crew.

When shiping, the five people did not do any work other than the their prime work. With a crew of up to 50 peoples, all jobs will be organized if the five heads coordinate and head each other's parts. The head of the chef was not alone in providing food for the entire crew, he will be assisted by other crew members. Kuanca was also not alone in his work to repair and maintain ship engines. Kuanca will be assisted by several ABKs, but only the responsibility was given to him. As with the kepala palung, this position was very important like the tekong. Kepala palung must have expertise in reading the situation during the fishing process. The coordination between the kepala palung and tekong greatly affected the catch because the tekong had to follow the command from the kepala palung quickly so that the maximum catch can be obtained.

The struggle for tekong -mostly Acehnese or Mandailingnes- often occured between juragan if the tekong have experties, reliabilities, lenght experienced and the greatest among the other tekong. The people called them as "tekong top". In order to keep the tekong from moving to another juragan, the juragan must pay more attention to the tekong. Juragan give some incentives. Not only additional money, and bonuses received, but the juragan was also prividing facilities such as a car or home and other luxury goods, to the tekong. By providing facilities and a lot of bonuses, the tekong has a "debt" to the juragan and finally the tekong became bound to them. 
Table 5 Modernization in Phase of Purse Seine 2000-now

\begin{tabular}{|c|c|c|}
\hline Characteristics & Description & \\
\hline a. Typologi Mode of Production & $\begin{array}{l}\text { Commercialist and } \\
\text { Production }\end{array}$ & Capitalist \\
\hline $\begin{aligned} & \text { b. } \text { Force of Production } \\
& \text { - } \text { Ships } \\
& \text { - } \text { Fishing gear } \\
& \text { - } \text { Mean of production } \\
& \text { - } \text { Labor } \\
&\end{aligned}$ & $\begin{array}{ll}\text { - } & \text { Purse Seine (30-100 GT) } \\
\text { - } & \text { Purse Seine } \\
\text { - } & \text { Modern } \\
\text { - } & \text { Permanent laborer } \\
\end{array}$ & \\
\hline 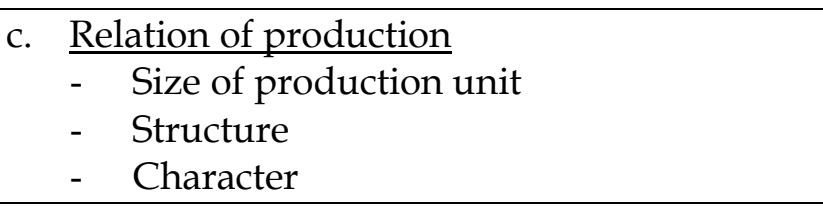 & $\begin{array}{ll}\text { - } & 50 \text { men } \\
\text { - } & \text { Hierarchical } \\
\text { - } & \text { Eksploitative }\end{array}$ & \\
\hline d. Marine product & Pelagic & \\
\hline $\begin{array}{l}\text { e. Ship Owner's Control Level } \\
\text { - Economic relations (control of what is } \\
\text { - produced) } \\
\text { 1. Control Relations } \\
\text { 2. Control of production tools } \\
\text {. Control labors }\end{array}$ & $\begin{array}{ll}\text { - } & \text { Partial control } \\
\text { - } & \text { Partial control } \\
\end{array}$ & \\
\hline
\end{tabular}

Source: Primary data processed (2016)

The structure of the division of labor in the purse seine can be seen in Figure 4 .

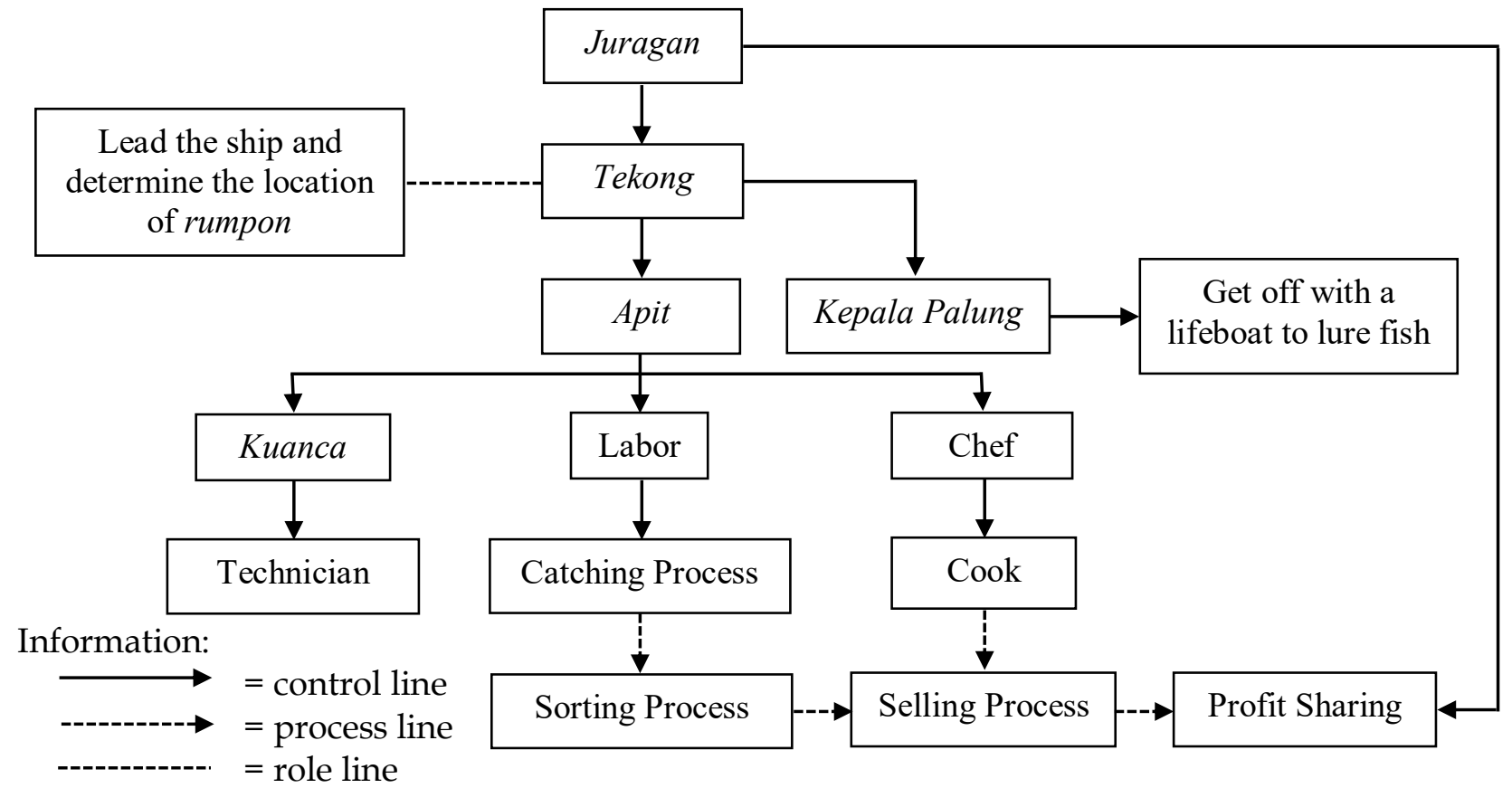

Figure 4 Organizational Structure in Purse Sein Period

Opposite the tekong, the juragan tied the crew by giving them a debt. Most crews employed were permanent fishermen who were bounded by debt. During fishing about 1-4 trips, all food consumed by ABK was calculated as debt. With these debts,
ABK became a non-free laborer who can't move to other juragan. ABK became a kind of permanent worker.

There were differences in production relations among juragan Bengkulu and Chinese. This difference was found in the 
wage system. Juragan Bengkulu used a profit sharing system while the Chinese a dayli salary system. So that the mode of production on the purse seine ship of the juragan Bengkulu was classified as a commercialist while in the Chinese was capitalist.

The profit sharing system carried out by juragan Bengkulu was revenue after deducting the production costs, $70 \%$ for juragan and $30 \%$ for labor fishermen. The $30 \%$ portion then divided into $20 \%$ for a tekong, $10 \%$ for a apit and $70 \%$ for other laborers. While the labor salary system in juragan Chinese was carried out $\operatorname{Rp} 50.000$ to 100.000 a day. Most salary systems were carried out by juragan Chinese with Purse Seine or tuna fishing ships. Salary system effective in minimizing the uncertainty experienced by labor when returning home does not bring hauls. There were no a noneconomic tied like a profit sharing system.

\section{CONCLUSION}

This research draw three conclusion as presented below.

1. In early 1960s when many Bugisnese came to Pulau Baai area, they used lancang with outboard motors as transportation mode and fishing fleet. The title of juragan was introduced in the Trawl period signed by arrival of several bosses from the Sibolga area in the 1980s. Then, bagan began came in Pulau Baai in 1980 and exist in 1990 with technological advances such as radar and computers in 1997. In 2000 a juragan from Bengkulu bought purse seine, the largest fishing ships in Bengkulu Province.
2. The force of production in every phase of modernization can be explained as follow. First, in phase of lancang fishermen used lancang as boat and fishing gear was net and fishing rod. Second, phase of trawl with a fleet of trawl ships and trawl fishing gear (trawls). Third was bagan phase with a fleet of bagan ships and fishing gear was lift net. Finally, in purse seine phase with a purse seine ship and fishing gear called purse seine too.

3. The relations of production in every phase of modernization can be summarized as follow. Lancang was subsistence production, trawl phase was commercial production, bagan phase was commercial production, and purse seine phase there were two production relations called commercial production and capitalist production.

\section{BIBLIOGRAPHY}

Arios, R. L. and Ajisman. 2003. Etos Kerja Masyarakat Nelayan di Kecamatan Silebar Kota Bengkulu Provinsi Bengkulu. Laporan Penelitian BKSNT Padang.

[BPS] Badan Pusat Statistik. 2015. Produksi Perikanan Tangkap Menurut Provinsi dan Subsektor.

Bungin, B. 2007. Penelitian Kualitatif. Jakarya: Prenada Media Grup

Kahn, J. S. 1980. Minangkabau Social Formations: Indonesian Peasants and The World-Economy. New York: Cambridge University Press.

Sanderson, S. K. 2000. Makro Sosiologi. Jakarta: Raja Grafindo Persada. 
Satria, A. 2001. Dinamika Modernisasi Perikanan: Formasi Sosial dan Mobilitas Nelayan. Bandung: Humaniora Utama Press

Stzompka, P. 2004. Sosiologi Perubahan Sosial. Jakarta: Prenada Media.

Sukmawati, D. 2008. Struktur dan Pola Hubungan Sosial Ekonomi Juragan dengan Buruh (Studi tentang Simbiosis antara Juragan dengan Nelayan Buruh di Pondok Bali Kecamatan Legon Kulon Kabupaten Subang). Jurnal Kependudukan Padjadjaran, 10(1): 63
Taylor, J. G. 1979. From Modernization to Mode of Production. London: The Macmillan Press.

Wijayanti, N. 2008. Pola Hubungan Kerja Antara Nelayan Pemilik Kapal Purse Seine Dengan Buruh Di Pangkalan Pendaratan Ikan (PPI) Unit 2 Pantai Utara Desa Bajomulyo Kecamatan Juwana Kabupaten Pati (Studi Deskriptif Kualitatif Mengenai Pola Hubungan Kerja Antara Nelayan Pemilik Kapal Purse Seine Dengan Buruh Di Pangkalan Pendaratan Ikan (PPI) Unit 2 Pantai Utara Desa Bajomulyo Kecamatan Juwana Kabupaten Pati. Thesis (Unpublished). Surakarta: Universitas Sebelas Maret. 